\title{
The kinetic properties of the glutamate dehydrogenase of Teladorsagia circumcincta and their significance for the lifestyle of the parasite
}

\author{
Noorzaid Muhamad a, David C. Simcock ${ }^{\text {b }}$, Kevin C. Pedley ${ }^{\text {b }}$, Heather V. Simpson ${ }^{\text {c }}$, Simon Brown ${ }^{\text {d,* }}$ \\ a Faculty of Medicine and Health Sciences, Universiti Malaysia Sarawak, 93150 Kuching, Sarawak, Malaysia \\ b Institute of Food, Nutrution and Human Health, Massey University, Private Bag 11222, Palmerston North, New Zealand \\ c Institute of Veterinary and Biomedical Sciences, Massey University, Private Bag 11222, Palmerston North, New Zealand \\ d School of Human Life Sciences, University of Tasmania, Locked Bag 1320, Launceston, Tasmania 7250, Australia
}

\section{A R T I C L E I N F O}

\section{Article history:}

Received 22 December 2010

Received in revised form 27 January 2011

Accepted 30 January 2011

Available online 4 February 2011

\section{Keywords:}

Enzyme kinetics

Glutamate dehydrogenase

Nitrogen metabolism

Teladorsagia circumcincta

\begin{abstract}
A B S T R A C T
Like other nematodes, both $\mathrm{L}_{3}$ and adult Teladosagia circumcincta secrete or excrete $\mathrm{NH}_{3} / \mathrm{NH}_{4}^{+}$, but the reactions involved in the production are unclear. Glutamate dehydrogenase is a significant source $\mathrm{NH}_{3} / \mathrm{NH}_{4}^{+}$in some species, but previous reports indicate that the enzyme is absent from $\mathrm{L}_{3}$ Haemonchus contortus. We show that glutamate dehydrogenase was active in both $\mathrm{L}_{3}$ and adult $T$. circumcincta. The apparent $K_{\mathrm{m}} \mathrm{S}$ of the $\mathrm{L}_{3}$ enzyme differed from those of the adult enzyme, the most significant of these being the increase in the $K_{\mathrm{m}}$ for $\mathrm{NH}_{4}^{+}$from $18 \mathrm{mM}$ in $\mathrm{L}_{3}$ to $49 \mathrm{mM}$ in adults. The apparent $V_{\max }$ of the oxidative deamination reaction was greater than that of the reductive reaction in $\mathrm{L}_{3}$, but this was reversed in adults. The activity of the oxidative reaction of the $L_{3}$ enzyme was not affected by adenine nucleotides, but that of the reductive reaction was stimulated significantly by either ADP or ATP. The $\mathrm{L}_{3}$ enzyme was more active with $\mathrm{NAD}^{+}$than it was with $\mathrm{NADP}^{+}$, although the activities supported by NADH and NADPH were similar at saturating concentrations. While the activity of the oxidative reaction was sufficient to account for the $\mathrm{NH}_{3} / \mathrm{NH}_{4}^{+}$efflux we have previously reported, the reductive amination reaction was likely to be more active.
\end{abstract}

(c) 2011 Elsevier Inc. All rights reserved.

\section{Introduction}

Both $\mathrm{L}_{3}$ and adult $T$. circumcincta secrete or excrete $\mathrm{NH}_{3} / \mathrm{NH}_{4}^{+}$ (Muhamad et al. 2004; Simpson et al. 2009), but the metabolic sources have not been identified. About sixty enzymes catalyse reactions involving $\mathrm{NH}_{3} / \mathrm{NH}_{4}^{+}$(Moss 2009) and only some of these are found in multicellular eukaryotes (for example, nitrogenase is restricted to bacteria). Of the latter, an important example is glutamate dehydrogenase (E.C. 1.4.1.3) which catalyses the reversible oxidative deamination of glutamate according to the reaction

glutamate $+\mathrm{NAD}(\mathrm{P})^{+}+\mathrm{H}_{2} \mathrm{O} \rightleftharpoons \alpha-$ ketoglutarate $+\mathrm{NAD}(\mathrm{P}) \mathrm{H}+\mathrm{NH}_{4}^{+}$

where the cofactor can be $\mathrm{NAD}^{+}$or $\mathrm{NADP}^{+}$with differing reaction efficiency. The activity of the enzyme is allosterically controlled by adenine nucleotides in mammals (Bailey et al. 1982; Hornby et al. 1984), but not in bacteria or fungi (Hudson and Daniel, 1993; Smith and Stanley, 2008). Despite considerable research, the mechanism of

\footnotetext{
* Corresponding author. Tel.: +613 63245400; fax: +61363243995.

E-mail address: Simon.Brown@utas.edu.au (S. Brown).
}

the allosteric control of glutamate dehydrogenase is yet to be elucidated (Smith and Stanley, 2008; Laskowski et al. 2009).

In most species glutamate dehydrogenase provides both a means for incorporating $\mathrm{NH}_{3} / \mathrm{NH}_{4}^{+}$into amino acids and of generating $\alpha$ ketoglutarate and $\mathrm{NH}_{3} / \mathrm{NH}_{4}^{+}$depending on the circumstances (Marzluf 1981; Magasanik 2003). However, Skuce et al. (1999) were able to detect neither glutamate dehydrogenase mRNA nor the protein in $\mathrm{L}_{3}$ $H$. contortus, although they were able to detect both in adult nematodes and the enzyme is present in adult $H$. contortus (Rhodes and Ferguson, 1973; Kapur et al. 1984). The absence of the protein from $\mathrm{L}_{3} H$. contortus is unusual because of the importance of glutamate dehydrogenase in most species. Moreover, if the enzyme were also absent from $\mathrm{L}_{3} T$. circumcincta then it could not be a source of the secreted or excreted $\mathrm{NH}_{3} / \mathrm{NH}_{4}^{+}$we have observed (Muhamad et al. 2004; Simpson et al. 2009). Therefore, we investigated the presence of the enzyme activity in $\mathrm{L}_{3}$ and adult $T$. circumcincta in order to determine whether the enzyme could be involved in the generation of the $\mathrm{NH}_{3} / \mathrm{NH}_{4}^{+}$that is secreted or excreted by the nematode (Muhamad et al. 2004; Simpson et al. 2009). We have characterised the kinetics of the enzyme in both $\mathrm{L}_{3}$ and adult $T$. circumcincta to assess this possibility, but also to (i) provide a comparison with the enzyme of other gut flora and the sheep and (ii) to develop insight into the parasitic lifestyle of $T$. circumcincta. 